\title{
Soil compaction and arbuscular mycorrhizae affect seedling growth of three grasses
}

\author{
Mark Thorne $^{1^{*}}$, Landon Rhodes ${ }^{2}$, John Cardina ${ }^{3}$ \\ ${ }^{1}$ Environmental Science Graduate Program, The Ohio State University, Columbus, USA; \\ *Corresponding Author: thorne.36@osu.edu \\ ${ }^{2}$ Department of Plant Pathology, The Ohio State University, Columbus, USA \\ ${ }^{3}$ Department of Horticulture and Crop Science, Ohio Agricultural and Research Development Center, The Ohio State University, \\ Wooster, USA
}

Received 26 September 2013; revised 27 October 2013; accepted 5 November 2013

Copyright (C) 2013 Mark Thorne et al. This is an open access article distributed under the Creative Commons Attribution License, which permits unrestricted use, distribution, and reproduction in any medium, provided the original work is properly cited.

\section{ABSTRACT}

Soil compaction is a limitation to establishment of native forest species on reclaimed surfacemined lands in Appalachia. Previously, non-native forage species such as tall fescue (Schedonorus arundinaceus (Schreb.) Dumort., nom. cons.) have been planted because they easily established on reclaimed mine soil. There is now interest in establishing robust native prairie species to enhance biodiversity and provide greater potential for root activity in the compacted soil. We conducted a 10-week glasshouse study comparing growth of "Pete" eastern gamagrass (Tripsacum dactyloides L.), "Bison" big bluestem (Andropogon gerardii Vitman), and "Jesup MaxQ" tall fescue at soil bulk densities (BD) of 1.0, 1.3, and $1.5 \mathrm{~g} \mathrm{~cm}^{-3}$. We also examined effects of arbuscular-mycorrhizal fungi (AMF) on plant growth in relation to compaction. Sources of AMF were a reclaimed surface coal mine soil and a native tallgrass prairie soil. Shoot and root biomass of tall fescue and big bluestem were reduced at 1.5 BD while eastern gamagrass growth was not affected. Growth of big bluestem and eastern gamagrass was greater with AMF than without, but similar between AMF sources. Tall fescue growth was not enhanced by AMF. Overall, tall fescue biomass was 3 times greater than eastern gamagrass and 6 times greater than big bluestem when comparing only AMF-colonized grasses. Eastern gamagrass and big bluestem are both slower to establish than tall fescue. Eastern gamagrass appears to be more tolerant of compaction, while big bluestem appears somewhat less tolerant.
Keywords: Soil Compaction; Arbuscular Mycorrhizae; Prairie Grass Establishment

\section{INTRODUCTION}

Soil compaction is a major limiting factor in restoring native vegetation on reclaimed surface mined land in the Appalachian coal mining region of the eastern USA [1-5]. Bulk densities of up to $1.8 \mathrm{~g} \cdot \mathrm{cm}^{-3}$ to depths of at least 60 $\mathrm{cm}$ have been recorded following use of heavy equipment to redistribute and contour overburden and stockpiled topsoil during reclamation [6]. Soil compaction limits available water and nutrients, reduces pore volume, restricts root elongation and development, reduces plant growth, and leads to anaerobic conditions that many plants are unable to tolerate [7-11].

Ameliorating soil compaction on reclaimed mine land is possible with deep tillage $[6,12,13]$. Tillage can reduce bulk density and improve water infiltration and has been used extensively in agriculture; however, deep tillage requires heavy equipment and high levels of energy input $[12,13]$ and disrupts developing soil structure and beneficial micro-organisms such as AMF [14,15]. An alternative to tillage is to establish deep-rooting plant species that can penetrate the soil and increase organic matter and biological activity in compacted regions of the profile. Roots that grow into compacted soil create channels that increase water flow and root access of other species to deeper regions of the soil profile otherwise not available because of the compaction [7,16-19]. Tap rooted annual plants are often used in agricultural systems; however, perennial species such as alfalfa may be more effective because of long-term growth and deeper rooting characteristics. Using perennial species would also eliminate the need for annual tillage, fertilization, and planting associated with annual cropping. 
Tall fescue is a perennial non-native forage grass that has been planted extensively on reclaimed surface-mined land in Appalachia [5]. Tall fescue is very productive $[20,21]$ and establishes within the five-year window mining companies have to establish a vegetation cover on reclaimed surface-mined land. However, tall fescue productivity declines over time on mine soil without organic amendments or legumes supplying nitrogen and phosphorus [22]. Furthermore, planting a limited number of non-native forages on reclaimed mine soil results in low diversity across the landscape.

Establishing large-statured, robust prairie species as an alternative to low-diversity forage complexes, might improve soil conditions on reclaimed mine land over time. Big bluestem and eastern gamagrass are warm-season C4 grasses native to prairies in the Midwest and southeastern US [23]. Big bluestem is dominant in tallgrass prairies and historically comprised as much as 90\% canopy cover within its range [24]. Eastern gamagrass is a robust perennial relative of corn (Zea mays L.) and is prevalent in the southern tallgrass prairies regions; however, this species has declined over time with overgrazing and tillage-based agriculture [25]. Furthermore, eastern gamagrass is able to root through compacted soil layers and tolerates periodic flooding [25-27].

Warm-season prairie grasses tend to have coarser root systems than cool-season grasses but thrive in soils with low available nutrients, especially $\mathrm{P}$, because of the symbiotic association with AMF [28-30]. The importance of AMF to plant survival in low $\mathrm{P}$ soil is well documented [31,32], but AMF is also important for plants growing in compacted soil $[10,33]$. Establishment of warm-season prairie grasses on reclaimed mine soil may help ameliorate mine soil compaction and increase community diversity, but only if AMF associated with the mine soil are effective and will benefit the prairie grasses. The objectives of this research are 1) to compare the early growth of tall fescue with that of big bluestem and eastern gamagrass in compacted soil; 2) to compare effects of AMF from reclaimed mine soil with AMF from native tallgrass prairie soil; and 3) to examine the interaction between soil compaction and AMF in relation to grass seedling growth.

\section{MATERIALS AND METHODS}

\subsection{AMF Sources and Pot Culture}

Sources of AMF were the Claridon (CL) tallgrass prairie remnant near Marion, Ohio, and the Wilds (WL), a reclaimed surface mined area near Cumberland, Ohio. The CL site is a 2.2 ha linear remnant owned by the CSX Railroad and is overseen by the Marion County Historical Society [34]. The WL site is located on land that had been surface mined in the early 1980s, and was once part of the Muskingum Mine, then owned and mined by Central Ohio Coal Company, but was donated in 1986 to The International Center for the Preservation of Wild Animals, Inc. (the Wilds). The area is part of the Allegheny Plateau of southeast Ohio, which extends westward from the Allegheny Mountains and is a subdivision of the Appalachian Mountain Range.

Approximately $35 \mathrm{~L}$ of surface topsoil were collected at each site during September, 2005 from 15 to 20 randomly selected locations at each site using a metal shovel to a depth of $20 \mathrm{~cm}$. At the CL location, samples were collected along side of established prairie grasses, including big bluestem and Indiangrass, so that grass roots containing AMF would be included. At the WL location, soil was collected from an area supporting non-native forage grasses and legumes including Kentucky bluegrass (Poa pratensis L.), tall fescue, and birds-foot trefoil (Lotus corniculatus L.). These species were prevalent throughout the reclaimed mined area.

Pot cultures of each AMF source were prepared by mixing soil from each location 1:1 by volume with silica sand in a portable cement mixer. The soil/sand mix was poured into $3.8-\mathrm{L}$ plastic nursery containers and sown with white clover (Trifolium repens L.) as a host plant for the AMF [35]. The clover was inoculated with rhizobia to insure nitrogen fixation. The containers were placed on benches in a $20^{\circ} \mathrm{C}$ to $27^{\circ} \mathrm{C}$ glasshouse with artificial lighting $12 \mathrm{hr}^{-}$day $^{-1}$. The pot cultures were watered daily without fertilizer for 10 months. Soil and fine roots were collected from each pot, mixed 1:1 with sterile soil/sand mix, and repotted and seeded with white clover and sideoats grama (Bouteloua curtipendula (Michx.) Torr.) for a second pot-culture cycle. After 4 months, watering ceased and the pots were moved to an artificially-lighted $16^{\circ} \mathrm{C}$ to $18^{\circ} \mathrm{C}$ room until the white clover and sideoats grama had wilted and dried. Fine roots and soil were collected from each pot and then mixed together for each AMF source and stored in plastic bags at $4^{\circ} \mathrm{C}$ for several days before being used in the experiment.

Sterile growing medium was prepared by sieving topsoil collected from the surface $20-\mathrm{cm}$ at the Wilds through a $6-\mathrm{mm}$ sieve. The sieved soil was then steamed for $5 \mathrm{hr}$ at $100^{\circ} \mathrm{C}$ and rested in plastic bins at $20^{\circ} \mathrm{C}$ prior to use in the experiment. The sterilized mine soil and the WL and CL pot-culture soils were analyzed by the Service Testing and Research Laboratory (STAR lab), The Ohio State University/Ohio Agricultural Research and Development Center, Wooster, OH (Table 1). A noninoculated (NI) control was included using the sterilized growing medium soil described above. Identification of AMF to species was not attempted for this study.

\subsection{Experimental Design and Establishment}

Experimental design was a randomized complete 
Table 1. Soil properties of reclaimed mine soil and arbuscular mycorrhizal fungi (AMF) pot-culture soil used in a 10-week glasshouse study examining the affects of soil compaction and AMF on the growth of three grass species.

\begin{tabular}{cccc}
\hline & \multirow{2}{*}{$\begin{array}{c}\text { Mine } \\
\text { topsoil }\end{array}$} & \multicolumn{2}{c}{ AMF pot culture soil } \\
\cline { 3 - 4 } Soil Parameter & & WL & $\mathrm{CL}$ \\
\hline $\mathrm{pH}$ & 7.3 & 7.9 & 7.7 \\
$\mathrm{P}\left(\mathrm{mg} \cdot \mathrm{kg}^{-1}\right)$ & 12 & 7 & $<1$ \\
$\mathrm{~K}\left(\mathrm{mg} \cdot \mathrm{kg}^{-1}\right)$ & 161 & 41 & 77 \\
$\mathrm{Ca}\left(\mathrm{mg} \cdot \mathrm{kg}^{-1}\right)$ & 3768 & 1262 & 1345 \\
$\mathrm{Mg}\left(\mathrm{mg} \cdot \mathrm{kg}^{-1}\right)$ & 321 & 198 & 235 \\
\hline
\end{tabular}

Soil P analyzed with Bray P1 method; $\mathrm{K}, \mathrm{Ca}$, and $\mathrm{Mg}$ analyzed with ammonium acetate extract method by STAR lab, Wooster, OH. "Soil collected from the 0 to 20 -cm surface layer at the Wilds 30 -yr reclaimed surface mine land near Cumberland, $\mathrm{OH} .{ }^{\S} \mathrm{WL}$ collected from the Wilds mine soil supporting non-native forage grasses. CL collected from Claridon tallgrass prairie remnant near Marion, $\mathrm{OH}$.

block with a factorial arrangement of three grass species, three soil compaction levels, and three AMF treatments; each complete block was replicated six times. Experimental units consisted of individual plants growing in polyvinyl chloride (PVC) tubes measuring 8 -cm inside diameter by $30-\mathrm{cm}$ deep. The inside of each tube was coated with copper hydroxide (SpinOut ${ }^{\circledR}$ root growth regulator, American Hydrotech, Inc., Chicago, IL.) to prevent roots from growing down the inside walls of the tubes to avoid the compacted soil medium. Soil was mixed individually for each tube by measuring an appropriate amount of sterile soil, on a dry weight basis, plus $120 \mathrm{~cm}^{3}$ AMF-inoculum soil, to yield bulk densities (BD) of $1.0,1.3$ and $1.5 \mathrm{~g}^{\cdot} \mathrm{cm}^{-3}$. The NI control tubes were filled only with sterile soil. Compaction levels were established by filling tubes in $5-\mathrm{cm}$ increments with a measured amount of soil to give the desired BD. A solid-wood plunger with $5-\mathrm{cm}$ reference lines, slightly smaller in diameter than the PVC tubes, was pressed down on the soil while the bottom of tube was simultaneously tapped on a concrete floor. Tapping continued until the appropriate reference line for each depth lined up with the top of the tube.

Seeds of "Jesup MaxQ" tall fescue, "Bison" big bluestem and "Pete" eastern gamagrass were germinated in Petri dishes and transplanted into each tube. After transplanting, the soil surface was covered with a layer of vermiculite to prevent drying and cracking. Each tube was then standardized for bacteria by adding $100 \mathrm{ml}$ of sievate corresponding to each particular AMF inoculum. The sievate for each inoculum was prepared by mixing $1000 \mathrm{~cm}^{3}$ pot culture soil and $16 \mathrm{~L}$ water, allowing the slurry to settle for a few seconds, and pouring the liquid and suspended matter through a $53-\mu \mathrm{m}$ sieve. Sievate from the WL inoculum was applied to the NI tubes. The tall fescue cultivar used in this study contained a nontoxic endophyte so as to avoid inhibition of AMF growth and colonization within AMF-inoculated tall fescue plants [36-38].

The 27 tubes in each block were randomly arranged in three rows containing nine tubes each, in a $43 \times 122-\mathrm{cm}$ wooden rack fitted into a $10 \times 60 \times 122$-cm plastic tub. Each tube was placed on a $10 \times 8 \times 10$-cm block of floral foam (Aquafoam ${ }^{\circledR}$, Syndicate Sales, Inc., Kokomo, IN). Holes were cut in the sides of the tubs $1 \mathrm{~cm}$ from the bottom for drainage and the tubes were watered daily as needed without fertilizer. The tubes were placed on benches in a glasshouse under artificial lighting set to maintain a minimum of $300 \mathrm{~W} \cdot \mathrm{m}^{-2} 16 \mathrm{~h} \cdot \mathrm{day}^{-1}$, and temperature set to range $19^{\circ} \mathrm{C}$ to $27^{\circ} \mathrm{C}$. Block establishment was staggered in two sets of three blocks so that harvest of the plants would not occur at the same time, and yet maintain an overall 10 -week growing period. The experiment was conducted in 2008 from April through July to take advantage of increasing natural day length, and moderate outside temperatures.

\subsection{Plant Growth and AMF Measurements}

At the end of the 10-week growth period, plant height (highest culm), number of leaves and tillers, aboveground (shoot) biomass, root biomass, and AMF colonization were measured. Shoots were clipped at the soil surface and soil was washed from the roots. Shoots and roots were placed in separate paper bags and dried at $55^{\circ} \mathrm{C}$ for a minimum of $96 \mathrm{hr}$, then weighed. Root to shoot ratio (RSR) was calculated by dividing root dry weight by shoot dry weight. Three small root sub-samples of $10 \times 25 \mathrm{~mm}$ were cut from each root length for assessment of AMF colonization.

\subsection{AMF Colonization Assessment}

Root samples were cleared and stained according to a modified Phillips and Hayman procedure [39]. During processing, root samples from each plant were contained in $5 \times 28 \mathrm{~mm}$ tissue processing cassettes (Canemco Inc., Quebec, Canada). Roots were cleared in $10 \% \mathrm{KOH}$ solution and autoclaved at $130^{\circ} \mathrm{C}$ for $10 \mathrm{~min}$, and then acidified in a $1 \%$ HCL solution for $20 \mathrm{~min}$ at room temperature to improve staining. Roots were stained in $0.05 \%$ Trypan blue staining solution containing 1:2:1 distilled water, lactic acid, and glycerin, and autoclaved for $7 \mathrm{~min}$ at $130^{\circ} \mathrm{C}$. Following staining, roots were rinsed in tap water and stored in plastic Petri dishes covered with a 1:1 solution of distilled water and glycerin and kept in a $4^{\circ} \mathrm{C}$ cooler. Colonization was assessed using a gridline intersect method [40,41]. For each sample, the first 50 roots bisecting gridlines scored $13 \mathrm{~mm}$ apart on the bottom of a Petri dish were designated colonized if the root 
segment contained hyphae, arbuscules, or vesicles. Percent colonization was calculated by dividing the number colonized by 50 , then multiplying by 100 .

\section{STATISTICAL ANALYSIS}

Data were analyzed using PROC GLM in SAS/ STAT $^{\circledR}$ software [42] and significance was accepted at $\alpha$ $=0.05$. Independent variables were grass species, AMF inoculum, compaction level, and block. Dependent variables were leaf and tiller count, shoot and root biomass, RSR, and percent AMF root colonization. All data except AMF colonization were rank transformed [43] to address normality and equal variance issues; AMF percent colonization data were arcsine transformed. Post-hoc comparisons were made on transformed data using protected Fisher's LSD test and differences were accepted only if the P-value calculated by PROC GLM was equal or less than 0.05 [44]. For presentation, actual means were used in place of ranks, and the sine of the arcsine means were used to back-transform the colonization data.

\section{RESULTS}

\subsection{Soil Analysis}

The calcareous mine soil used in this study had $\mathrm{pH}$ of 7.3 , calcium (Ca) content of $3768 \mathrm{mg} \cdot \mathrm{kg}^{-1}$ and available $\mathrm{P}$ content of $12 \mathrm{mg} \cdot \mathrm{kg}^{-1}$ (Table 1). The basic $\mathrm{pH}$ and high $\mathrm{Ca}$ content is due to $\mathrm{CaCO}_{3}$ from limestone layers unearthed during the mining process $[45,46]$. In calcareous soil, $\mathrm{P}$ becomes unavailable for plant uptake as it binds with Ca to form calcium phosphate compounds [47, 48].

Availability of soil $\mathrm{P}$ depends on factors including parent material, soil $\mathrm{pH}$, temperature, total soil $\mathrm{P}$, and associated plant species [49-54]. Schubert and Hayman [55] found that AMF was not a benefit to plant growth when available soil $\mathrm{P}$ was greater than $50 \mathrm{mg} \cdot \mathrm{kg}^{-1}$, suggesting that the low $\mathrm{P}$ soil used in this experiment was limiting for growth of plants without AMF.

\subsection{AMF}

Percent AMF colonization was greatest for eastern gamagrass, but was similar between the WL or CL inoculums, averaging greater than $70 \%$ for both AMF sources (Table 2). In contrast, big bluestem and tall fescue both had greater colonization with WL AMF. Big bluestem was colonized $1.75 \times$ greater with WL, while tall fescue was colonized $3 \times$ greater with WL than CL AMF (Table 2). However, compaction had no effect on colonization as percentages were similar within each AMF source for each grass species.

Effectiveness of the AMF inoculums was also evaluated based on growth measurements at the completion of the 10-week study. The three-way interaction between grass species, AMF inoculum, and compaction level was not significant at $\alpha=0.05$ for any of the growth variables (data not shown); however, the interaction between grass species and AMF was significant for all variables. Plant growth averaged over compaction levels was similar for both WL and CL inoculums, but differed between grass

Table 2. Arbuscular mycorrhizal fungi (AMF) root colonization in three grasses growing in mine soil at three levels of soil compaction expressed as bulk density (BD) and averaged overall BD levels, during a 10-week glasshouse study.

\begin{tabular}{|c|c|c|c|c|c|}
\hline \multirow{3}{*}{ Grass species ${ }^{\dagger}$} & \multirow{3}{*}{ AMF Source } & \multicolumn{4}{|c|}{ AMF colonization $\S(\%)$} \\
\hline & & \multicolumn{3}{|c|}{ Bulk Density $\left(\mathrm{g} \cdot \mathrm{cm}^{-3}\right)$} & \multirow[t]{2}{*}{ Mean } \\
\hline & & $(1.0)$ & (1.3) & $(1.5)$ & \\
\hline \multirow[t]{3}{*}{ Tall fescue } & WL & 26 & 16 & 35 & $30 \mathrm{c}$ \\
\hline & $\mathrm{CL}$ & 10 & 7 & 12 & $10 \mathrm{~d}$ \\
\hline & NI & 0 & 0 & 0 & $0 \mathrm{~d}$ \\
\hline \multirow[t]{3}{*}{ Big bluestem } & WL & 51 & 62 & 45 & $56 \mathrm{~b}$ \\
\hline & $\mathrm{CL}$ & 17 & 42 & 35 & $32 \mathrm{c}$ \\
\hline & $\mathrm{NI}$ & 0 & 0 & 0 & $0 \mathrm{~d}$ \\
\hline \multirow[t]{3}{*}{ Eastern gamagrass } & WL & 82 & 67 & 61 & $76 \mathrm{a}$ \\
\hline & $\mathrm{CL}$ & 72 & 70 & 73 & $73 \mathrm{a}$ \\
\hline & NI & 0 & 1 & 0 & $0 \mathrm{~d}$ \\
\hline
\end{tabular}

${ }^{\dagger}$ Tall fescue (Schedonorus arundinaceus (Schreb.) Dumort., nom. cons.); big bluestem (Andropogon gerardii Vitman); eastern gamagrass (Tripsacum dactylloides L.). ${ }^{\ddagger}$ Sources of AMF are the Wilds (WL), a 30-year-old reclaimed surface mine area near Cumberland, OH, the Claridon (CL) tallgrass prairie remnant near Marion, $\mathrm{OH}$, and a control (NI). ${ }^{\S}$ Differences between AMF colonization, listed for each species across levels of soil bulk densities (BD) for each AMF source, were not significant at $\alpha=0.05$. 'Differences between means detected using Fisher's protected LSD $(\alpha=0.05)$ are designated with different letters. 
species (Table 3). At 10 weeks, tall fescue had produced more leaves, tillers, shoot biomass, and root biomass than either big bluestem or eastern gamagrass with no differences in growth between WL, CL, or NI. Tall fescue, with or without AMF, averaged 6 times more shoot biomass than AMF-colonized big bluestem and 3 times more than AMF-colonized eastern gamagrass (Table 3). An increase in biomass from AMF was only evident with big bluestem and eastern gamagrass. Biomass of AMFinoculated eastern gamagrass plants was twice that of AMF-inoculated big bluestem, and 13 - 14 times greater in biomass than NI eastern gamagrass. Shoot and root biomass of AMF-inoculated big bluestem was 50 - 110 times greater than NI big bluestem, which averaged only $0.01 \mathrm{~g}$ plant $^{-1}$ (Table 3).

In addition, presence of AMF also affected plant height as eastern gamagrass with AMF had twice the height of NI plants; big bluestem without AMF averaged only 13\% the height of AMF plants. Plant height of tall fescue was not affected by AMF (Table 3). When comparing the relationship between root and shoot biomass, NI big bluestem plants had 1.7 times greater RSR than AMF plants. Tall fescue and eastern gamagrass RSR was not affected by AMF (Table 3).

\subsection{Compaction}

The interaction between grass species and soil compaction was not significant at $\alpha=0.05$; however, the response of the each species to increasing soil compaction

Table 3. Interaction between grass species and arbuscular mycorrhizal fungi (AMF) on growth parameters in sterilized mine soil. Sources of AMF are the Wilds (WL), a 30-year-old reclaimed surface mine area near Cumberland, $\mathrm{OH}$, and the Claridon (CL) tallgrass prairie remnant near Marion, $\mathrm{OH}$, in a 10 -week glasshouse experiment.

\begin{tabular}{cccccccc}
\hline \multicolumn{7}{c}{ Growth parameters $^{\dagger}$} \\
\hline $\begin{array}{c}\text { Grass } \\
\text { SPP }^{\ddagger}\end{array}$ & AMF & LVS & TIL & HGT & SHT & RT & RSR \\
\hline \multirow{3}{*}{ TF } & WL & $77 \mathrm{a}$ & $19 \mathrm{a}$ & $37 \mathrm{c}$ & $6 \mathrm{a}$ & $4 \mathrm{a}$ & $0.7 \mathrm{~b}$ \\
& $\mathrm{CL}$ & $66 \mathrm{a}$ & $17 \mathrm{a}$ & $44 \mathrm{bc}$ & $6 \mathrm{a}$ & $4 \mathrm{a}$ & $0.6 \mathrm{~b}$ \\
& NI & $60 \mathrm{a}$ & $28 \mathrm{a}$ & $43 \mathrm{bc}$ & $6 \mathrm{a}$ & $4 \mathrm{a}$ & $0.6 \mathrm{~b}$ \\
$\mathrm{BB}$ & $\mathrm{WL}$ & $17 \mathrm{~cd}$ & $2 \mathrm{c}$ & $49 \mathrm{bc}$ & $1 \mathrm{c}$ & $0.6 \mathrm{c}$ & $0.8 \mathrm{~b}$ \\
& $\mathrm{CL}$ & $14 \mathrm{~d}$ & $1 \mathrm{~cd}$ & $49 \mathrm{bc}$ & $1 \mathrm{c}$ & $0.5 \mathrm{c}$ & $0.6 \mathrm{~b}$ \\
& NI & $6 \mathrm{e}$ & $1 \mathrm{~d}$ & $6 \mathrm{e}$ & $0.01 \mathrm{e}$ & $0.01 \mathrm{e}$ & $1.2 \mathrm{a}$ \\
EG & WL & $22 \mathrm{~b}$ & $4 \mathrm{~b}$ & $61 \mathrm{a}$ & $2 \mathrm{~b}$ & $1 \mathrm{~b}$ & $0.6 \mathrm{~b}$ \\
& $\mathrm{CL}$ & $20 \mathrm{bc}$ & $4 \mathrm{~b}$ & $55 \mathrm{ab}$ & $2 \mathrm{~b}$ & $1 \mathrm{~b}$ & $0.6 \mathrm{~b}$ \\
& NI & $6 \mathrm{e}$ & $1 \mathrm{~d}$ & $27 \mathrm{~d}$ & $0.1 \mathrm{~d}$ & $0.09 \mathrm{~d}$ & $0.7 \mathrm{~b}$ \\
\hline
\end{tabular}

${ }^{\dagger}$ LVS = leaf count; TIL = tiller count; HGT = culm height; SHT $=$ shoot biomass; RT = root biomass. Numbers in each column followed by the same letter are not different using Fisher's protected LSD $(\alpha=0.05)$. Values in each column are on a per plant basis. ${ }^{*}$ Tall fescue (TF) (Schedonorus arundinaceus (Schreb.) Dumort., nom. cons.); big bluestem (BB) (Andropogon gerardii Vitman); eastern gamagrass (EG) (Tripsacum dactyloides L.). was of particular interest in this study. The NI plants were not included in this analysis because big bluestem and eastern gamagrass are greatly dependent on AMF and likely don't exist in nature without the symbiotic relationship; therefore, including NI plants would bias the results in favor of the more facultative tall fescue. Since no difference was found between WL and CL AMF, data were combined over inoculum sources and the effect of soil compaction on each grass species was compared only with AMF-inoculated plants.

Tall fescue produced more shoot and root biomass than big bluestem or eastern gamagrass; however, production was reduced by increased compaction (Figure 1). As BD increased from 1.3 to 1.5 , tall fescue shoot biomass declined from 6.5 to $4.2 \mathrm{~g} \cdot$ plant $^{-1}$, and root biomass

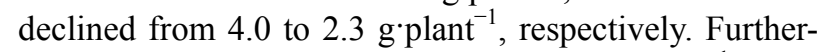
more, tall fescue averaged 22 and 17 tillers $\cdot$ plant $^{-1}$ at 1.0 and $1.3 \mathrm{BD}$, respectively, and only 14 tillers'plant ${ }^{-1}$ at 1.5 $\mathrm{BD}$; however, no difference was seen in culm height or RSR.

Big bluestem growth was also reduced by compaction as plants at 1.0 BD averaged 18 leaves and 2 tillers, but
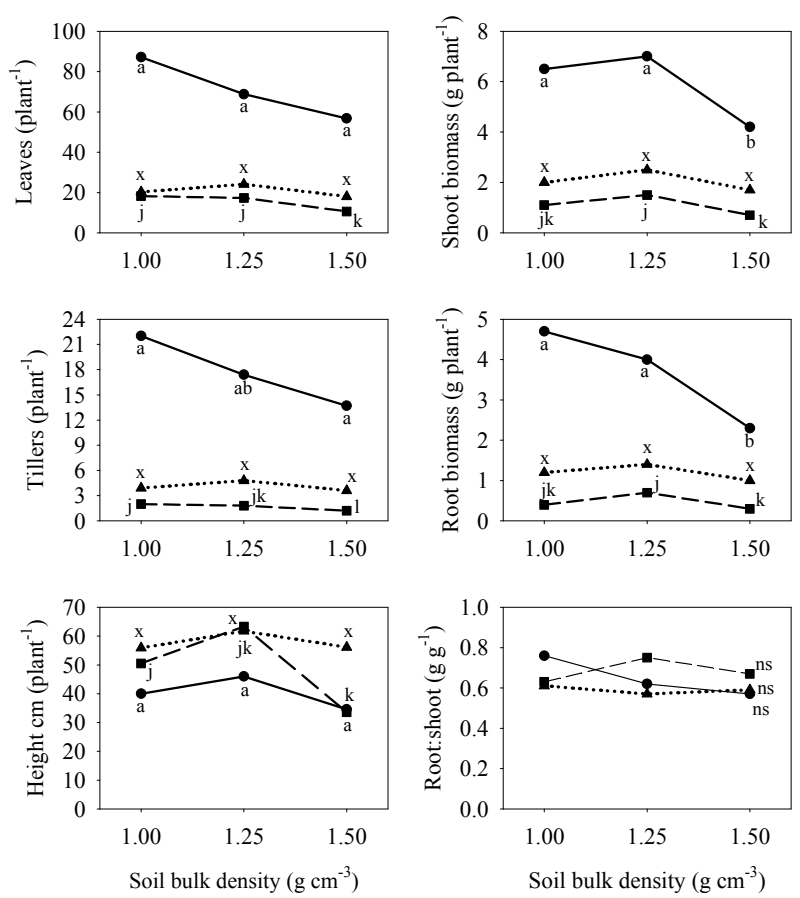

Figure 1. Relationships between grass species and soil compaction in sterile mine soil inoculated with arbuscular mycorrhizal fungi in a 10-week glasshouse study with tall fescue (Schedonorus arundinaceus (Schreb.) Dumort., nom. cons.) (- - -), big bluestem (Andropogon gerardii Vitman) (-- - - ), and eastern gamagrass (Tripsacum dactyloides L.) $(\cdots \mathbf{\Delta} \cdots)$. Differences among compaction levels, for each species, are compared with Fisher's protected LSD $(\alpha=0.05)$ and are shown by the following letters for each species: tall fescue (a, $b$, c), big bluestem $(\mathrm{j}, \mathrm{k}, \mathrm{l})$, eastern gamagrass $(\mathrm{x}, \mathrm{y}, \mathrm{z})$, and $\mathrm{ns}=$ non-significant. 
declined to 11 leaves and 1.2 tillers plant ${ }^{-1}$ at $1.5 \mathrm{BD}$; however, differences were not found between 1.0 and 1.3 BD (Figure 1). Increased compaction from 1.3 and 1.5 BD reduced culm height and shoot biomass $50 \%$ and root biomass by $40 \%$. Compaction had no affect on RSR for this species.

Eastern gamagrass was less affected by compaction as differences between compaction levels were not found in any of the growth measurements (Figure 1). Leaf counts averaged between 18 and 24, while tiller counts averaged

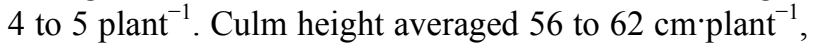
shoot biomass averaged 1.7 to $2.5 \mathrm{~g}$, and root biomass averaged 1.0 to $1.4 \mathrm{~g}$.plant ${ }^{-1}$ between the compaction levels (Figure 1). The RSR averaged 0.6 at each level of compaction.

\section{DISCUSSION}

Soil compaction, with BD from 1.0 to $1.5 \mathrm{~g} \cdot \mathrm{cm}^{-3}$, did not have an impact on AMF colonization levels. Tall fescue appeared to be a better host for WL AMF than CL AMF. This may be due to WL AMF being associated with tall fescue and other cool-season grass on the reclaimed mine soil; however, big bluestem also had greater colonization with WL than CL AMF, which would suggest that WL AMF may be more infective than CL AMF or that there is some degree of host specificity. Host specificity has been shown for other AMF cultures [56-59]. In contrast, eastern gamagrass showed no preference between the two AMF sources, but had greater AMF colonization than the other two grasses, especially tall fescue. Colonization levels are not always correlated with efficacy; however, higher colonization may reflect greater dependence, especially in coarse-rooted species such as eastern gamagrass [28,29].

Without AMF, it was apparent that neither big bluestem nor eastern gamagrass would have survived, especially in competition with tall fescue. Warm-season grasses, especially big bluestem, tend to be dependent on AMF when soil P is limited; whereas, cool-season grasses can establish with little or no AMF inoculum [28, $30,60,61]$. For example, root growth of tall fescue in this study was at least 6 times greater than big bluestem with AMF and over 350 times greater than big bluestem with no AMF (Table 3). Newman and Moser [62] found significantly greater adventitious root growth for tall fescue compared with big bluestem and other warm-season grasses at emergence of the third leaf during a glasshouse study; however, for big bluestem third leaf emergence occurred in 15 to 16 days compared with 28 to 32 days for tall fescue, suggesting tall fescue seedlings put early resources into root growth. In this study, eastern gamagrass with either AMF inoculum had 25\% less root growth than tall fescue with or without AMF.

Inoculation with either WL or CL was equally benefi- cial to big bluestem and eastern gamagrass, suggesting that the WL AMF would not be a limiting factor for establishing these grasses on the reclaimed mine soil. This finding is consistent with a related experiment that found no difference between the two AMF sources in affecting biomass accumulation [63]. In contrast, tall fescue is clearly able to establish quickly in low P soil, with or without AMF, which demonstrates why it has been widely used in reclamation of surface mined lands in the eastern USA [22]. The similarity between AMF and NI treatments supports other findings that tall fescue's association with AMF is highly facultative, and in the absence of AMF, can perform as well as AMF-colonized plants when soil is low in available $\mathrm{P}$ [64].

Warm-season prairie grasses are generally slower to establish than cool-season forage grasses $[62,65]$ and big bluestem and eastern gamagrass were consistent in this growth pattern. Both these species produced considerably less biomass than tall fescue during the 10-week experiment, but tall fescue had the greatest reduction of growth at the highest compaction level. Other research has also found a decrease in tall fescue biomass by compaction, especially in clay soil $[20,66]$. Our data showed that eastern gamagrass biomass was not different at any of the compaction levels, suggesting this species may be better suited for the compacted mine soil. Mine soil compaction on reclaimed surface-mined land in the Appalachian coal mining region can exceed compaction levels imposed in this research, particularly at lower depths $[6,67]$. Thus, species less able to penetrate compact soil would potentially limit their root growth to less compacted soil near the surface, which could reduce soil development at lower compacted depths where anaerobic conditions may be present. Eastern gamagrass can develop cellular compartments (aerenchyma) that allow air flow into deep roots [25-27] which may assist root growth deep into compacted soil where oxygen levels may be low. Eastern gamagrass has been successfully planted in hedgerows for erosion and runoff control, further suggesting tolerance of flooding [68,69], and is as productive as switchgrass (Panicum virgatum L.) in paired plantings, producing as much as $1395 \mathrm{~g} \cdot \mathrm{m}^{-2}$ [70].

\section{CONCLUSIONS}

Establishing native prairie grasses on compacted reclaimed mine soil is limited by adverse soil conditions. Tall fescue has been successful on reclaimed surfacemined land in the eastern USA coal mining region, but is not native to North America and is a major component of the low-diversity forage complex planted on mine soil. Tall fescue establishes quickly but is slightly inhibited by compact soil of at least $1.5 \mathrm{~g}^{\cdot} \mathrm{cm}^{-3} \mathrm{BD}$. Big bluestem is a dominant tallgrass prairie species that is slow to establish, but its growth appears to be reduced by compacted soil. 
Eastern gamagrass is native to the region and tolerates compacted and wet soil, and may be useful in ameliorating mine soil compaction, which would facilitate establishment of other native species. Eastern gamagrass is slower to establish than tall fescue, but is affected relatively less by compaction. The AMF associated with cool-season forage grasses on reclaimed mine soil in this study is suitable for establishment of warm-season AMFdependent prairie grasses like big bluestem and eastern gamagrass. Successful establishment of warm-season prairie grasses on compacted reclaimed mine soil will require effective $\mathrm{AMF}$ and considerably more time than cool season grasses such as tall fescue, but could useful in increasing biological diversity.

\section{ACKNOWLEDGEMENTS}

We thank Dr. Nicole Cavender for access to soil at The Wilds; Dr. Robert Klips for access to soil at the Claridon Prairie, and Dr. David Gardner and Dr. Kent Harrison for review of the manuscript. We also thank David Snodgrass and Jim Vent of the Howlett Greenhouse facility at The Ohio State University for assistance with this project. Salaries and research support were provided by state and federal funds appropriated to the Ohio Agriculture Research and Development Center, The Ohio State University. Manuscript No. HCS-13-14.

\section{REFERENCES}

[1] Larson, M.M. and Vimmerstedt, J.P. (1983) Evaluation of 30 -year-old plantations on strip-mined land in east central Ohio. Research Bulletin, The Ohio State University/Ohio Agricultural Research and Development Center, Wooster, 3-20.

[2] Kost, D.A., Larson, M.M., Vimmerstedt, J.P., Brown, J.H. and Houston, D.B. (1994) Final report: Reclamation of calcareous coal spoils with trees, shrubs, and forages. The Ohio State University/Ohio Agricultural Research and Development Center, Wooster.

[3] Zeleznik, J.D. and Skousen, J.G. (1996) Survival of three tree species on old reclaimed surface mines in Ohio. Journal of Environmental Quality, 25, 1429-1435. http://dx.doi.org/10.2134/jeq1996.0047242500250006003 $\underline{7 \mathrm{x}}$

[4] Haering, K.C., Daniels, W.L. and Galbraith, J.M. (2004) Appalachian mine soil morphology and properties: Effects of weathering and mining method. Soil Science Society of America Journal, 68, 1315-1325. http://dx.doi.org/10.2136/sssaj2004.1315

[5] Casselman, C.N., Fox, T.R., Burger, J.A., Jones, A.T. and Galbraith, J.M. (2006) Effects of silvicultural treatments on survival and growth of trees planted on reclaimed mine lands in the Appalachians. Forest Ecology and Management, 223, 403-414. http://dx.doi.org/10.1016/j.foreco.2005.12.020

[6] Shrestha, R.K., Lal, R. and Jacinthe, P.A. (2009) Enhancing carbon and nitrogen sequestration in reclaimed soils through organic amendments and chiseling. Soil
Science Society of America Journal, 73, 1004-1011. http://dx.doi.org/10.2136/sssaj2008.0216

[7] Unger, P.W. and Kaspar, T.C. (1994) Soil compaction and root growth: A review. Agronomy Journal, 86, 759-766. http://dx.doi.org/10.2134/agronj1994.0002196200860005 $\underline{0004 x}$

[8] Whalley, W.R., Dumitru, E. and Dexter, A.R. (1995) Biological effects of soil compaction. Soil and Till Research, 35, 53-68. http://dx.doi.org/10.1016/0167-1987(95)00473-6

[9] Bengough, A.G., Croser, C. and Pritchard, J. (1997) A biophysical analysis of root growth under mechanical stress. Plant and Soil, 189, 155-164. http://dx.doi.org/10.1023/A:1004240706284

[10] Nadian, H., Smith, S.E., Alston, A.M. and Murray, R.S. (1997) Effects of soil compaction on plant growth, phosphorus uptake and morphological characteristics of vesicular-arbuscular mycorrhizal colonization of Trifolium subterraneum. New Phytologist, 135, 303-311. http://dx.doi.org/10.1046/j.1469-8137.1997.00653.x

[11] Kozlowski, T.T. (1999) Soil compaction and growth of woody plants. Scandinavian Journal of Forest Research, 14, 596-619. http://dx.doi.org/10.1080/02827589908540825

[12] Sinnett, D., Poole, J. and Hutchings, T.R. (2006) The efficacy of three techniques to alleviate soil compaction at a restored sand and gravel quarry. Soil Use and Management, 22, 362-371. http://dx.doi.org/10.1111/j.1475-2743.2006.00053.x

[13] Croton, J.T. and Ainsworth, G.L. (2007) Development of a winged tine to relieve mining-related soil compaction after bauxite mining in western Australia. Restoration Ecology, 15, S48-S53. http://dx.doi.org/10.1111/j.1526-100X.2007.00292.x

[14] Jasper, D.A., Abbott, L.K. and Robson, A.D. (1989) Soil disturbance reduces the infectivity of external hyphae of vesicular-arbuscular mycorrhizal fungi. New Phytologist, 112, 93-99. http://dx.doi.org/10.1111/j.1469-8137.1989.tb00313.x

[15] Lal, R. (1993) Tillage effects on soil degradation, soil resilience, soil quality, and sustainability. Soil and Tillage Research, 27, 1-8. http://dx.doi.org/10.1016/0167-1987(93)90059-X

[16] Meek, B.D., DeTar, W.R., Rolph, D., Rechel, E.R. and Carter, L.M. (1990) Infiltration rate as affected by an alfalfa and no-till cotton cropping system. Soil Science Society of America Journal, 54, 505-508. http://dx.doi.org/10.2136/sssaj1990.03615995005400020 $\underline{036 x}$

[17] Cresswell, H.P. and Kirkegaard, J.A. (1995) Subsoil amelioration by plant roots-The process and the evidence. Australian Journal of Soil Research, 33, 221-239. http://dx.doi.org/10.1071/SR9950221

[18] Rasse, D.P. and Smucker, A.J.M. (1998) Root colonization of previous root channels in corn and alfalfa rotations. Plant and Soil, 204, 203-212. http://dx.doi.org/10.1023/A:1004343122448

[19] Williams, S.M. and Weil, R.R. (2004) Crop cover root 
channels may alleviate soil compaction effects on soybean crop. Soil Science Society of America Journal, 68, 1403-1409. http://dx.doi.org/10.2136/sssaj2004.1403

[20] Crews, J.T. (1984) Effect of minesoil compaction on growth and yield of KY-31 tall fescue and sericea lespedeza. Northeastern Forest Experiment Station, USDAForest Service, Berea.

[21] Sulc, R.M., McCormick, J.S., Rhodes, L.H., Barker, D.J. and Diedrick, K.A. (2006) Ohio forage performance trials. Horticulture and Crop Science Series 195, The Ohio State University, Columbus.

[22] Roberts, J.A., Daniels, W.L., Bell, J.C. and Martens, D.C. (1988) Tall fescue production and nutrient status on southwest Virginia mine soils. Journal of Environmental Quality, 17, 55-62.

http://dx.doi.org/10.2134/jeq1988.0047242500170001000 $\underline{8 \mathrm{x}}$

[23] Hitchcock, A.S. and Chase A. (1971) Manual of the grasses of the United States. 2nd Edition, Dover, New York.

[24] Weaver, J.E. (1931) Who's who among the prairie grasses. Ecology, 12, 623-632. http://dx.doi.org/10.2307/1929467

[25] Gilker, R.E., Weil, R.R., Krizek, D.T. and Momen, B. (2002) Eastern gamagrass root penetration in adverse subsoil conditions. Soil Science Society of America Journal, 66, 931-938. http://dx.doi.org/10.2136/sssaj2002.0931

[26] Clark, R.B., Alberts, E.E., Zobel, R.W., Sinclair, T.R., Miller, M.S., Kemper, W.D. and Foy, C.D. (1998) Eastern gamagrass (Tripsacum dactyloides) root penetration and chemical properties of claypan soils. Plant and Soil, 200, 33-45. http://dx.doi.org/10.1023/A:1004256100631

[27] Krizek, D.T., Ritchie, J.C., Sadeghi, A.M., Foy, C.D., Rhoden, E.G., Davis, J.R. and Camp, M.J. (2003) A fouryear study of biomass production of eastern gamagrass grown on an acid compact soil. Communications in Soil Science Plant Analysis, 34, 457-480. http://dx.doi.org/10.1081/CSS-120017832

[28] Hetrick, B.A.D., Leslie, J.F., Wilson, G.T. and Kitt, D.G. (1988) Physical and topological assessment of effects of a vesicular-arbuscular mycorrhizal fungus on root architecture of big bluestem. New Phytologist, 110, 85-96. http://dx.doi.org/10.1111/j.1469-8137.1988.tb00240.x

[29] Hetrick, B.A.D., Wilson, G.W.T. and Leslie, J.F. (1991) Root architecture of warm- and cool-season grasses: Relationship to mycorrhizal dependence. Canadian Journal of Botany, 69, 112-118. http://dx.doi.org/10.1139/b91-016

[30] Brejda, J.J., Yocom, D.H., Moser, L.E. and Waller, S.S. (1993) Dependence of 3 Nebraska Sandhills warm-season grasses on vesicular-arbuscular mycorrhizae. Journal of Range Management, 46, 14-20. http://dx.doi.org/10.2307/4002441

[31] Mosse, B. (1973) Plant growth responses to vesiculararbuscular mycorrhizae IV. In soil given additional phosphate. New Phytologist, 72, 127-136. http://dx.doi.org/10.1111/j.1469-8137.1973.tb02017.x

[32] Gerdemann, J.W. (1968) Vesicular-arbuscular mycorrhiza and plant growth. Annual Review Phytopathology, 6, 397-
418.

http://dx.doi.org/10.1146/annurev.py.06.090168.002145

[33] Miransari, M., Bahrami, H.A., Rejali, F., Malakouti, M.J. and Torabi, H. (2007) Using arbuscular mycorrhiza to reduce the stressful effects of soil compaction on corn (Zea mays L.) growth. Soil Biology and Biochemistry, 39, 2014-2026.

http://dx.doi.org/10.1016/j.soilbio.2007.02.017

[34] Klips, R.A. (2003) Vegetation of Claridon railroad prairie, a remnant of the Sandusky Plains of central Ohio. Castanea, 68, 135-142. http://www.jstor.org/stable/4034303

[35] Liu, R. and Wang, F. (2003) Selection of appropriate host plants used in trap culture of arbuscular mycorrhizal fungi. Mycorrhiza, 13, 123-127. http://dx.doi.org/10.1007/s00572-002-0207-4

[36] Chu-Chou, M., Guo, B., An, Z.Q., Hendrix, J.W., Ferriss, R.S., Siegel, M.R., Dougherty, C.T. and Burrus, P.B. (1992) Suppression of mycorrhizal fungi in fescue by the Acremonium coenophialum endophyte. Soil Biology and Biochemistry, 24, 633-637. http://dx.doi.org/10.1016/0038-0717(92)90041-U

[37] Guo, B.Z., Hendrix, J.W., An, Z.-Q. and Ferriss, R.S. (1992) Role of Acremonium endophyte of fescue on inhibition of colonization and reproduction of mycorrhizal fungi. Mycologia, 84, 882-885. http://dx.doi.org/10.2307/3760286

[38] Phillips, T.D. and Aiken, G.E. (2009) Novel-endophyteinfected tall fescues. Forage and Grazinglands. http://dx.doi.org/10.1094/FG-2009-1102-01-RV

[39] Phillips, J.M. and Hayman, D.S. (1970) Improved procedures for clearing roots and staining parasitic and vesicular-arbuscular mycorrhizal fungi for rapid assessment of infection. Transactions of the British Mycological Society, 5, 158-161. http://dx.doi.org/10.1016/S0007-1536(70)80110-3

[40] Newman, E.I. (1966) A method of estimating the total length of root in a sample. Journal of Applied Ecology, 3, 139-145. http://dx.doi.org/10.2307/2401670

[41] Giovannetti, M. and Mosse, B. (1980) An evaluation of techniques for measuring vesicular arbuscular mycorrhizal infection in roots. New Phytologist, 84, 489-500. http://dx.doi.org/10.1111/j.1469-8137.1980.tb04556.x

[42] SAS OnlineDoc, Version 9.1. (2007) SAS Institute Inc., Cary.

[43] Iman, R.L., Hora, S.C. and Conover, W.J. (1984) Comparison of asymptotically distribution-free procedures for the analysis of complete blocks. Journal of the American Statistical Association, 79, 674-685. http://dx.doi.org/10.1080/01621459.1984.10478096

[44] Milliken, G.A. and Johnson, D.E. (1984) Analysis of messy data. Volume I: Designed experiments. Wadsworth, Inc., Belmont.

[45] Brant, R.A. (1964) Geological description and effects of strip mining on coal overburden material. Ohio Journal of Science, 64, 68-75. http://hdl.handle.net/1811/4990

[46] Soil Survey Staff (1996) Soil survey of Muskingum County, Ohio. USDA-Natural Resource Conservation Service, Washington. 
[47] Brady, N.C. (1984) The nature and properties of soils. Macmillan Publishing, New York.

[48] McBride, M.B. (1994) Environmental chemistry of soils. Oxford University Press, Inc., New York.

[49] Pearson, R.W., Spry, R. and Pierre, H.W. (1940) The vertical distribution of total and dilute acid-soluble phosphorus in twelve Iowa soil profiles. Agronomy Journal, 32, 683-696.

http://dx.doi.org/10.2134/agronj1940.0002196200320009 $\underline{0005 x}$

[50] Barrow, N.J., Malajczuk. N. and Shaw, T.C. (1977) A direct test of the ability of vesicular-arbuscular mycorrhizae to help plants take up fixed soil phosphate. New Phytologist, 78, 269-276. http://dx.doi.org/10.1111/j.1469-8137.1977.tb04830.x

[51] Wuenscher, M.L. and Gerloff, G.C. (1977) Growth of $A n-$ dropogon scoparius (little bluestem) in phosphorus deficient soils. New Phytologist, 70, 1035-1042. http://dx.doi.org/10.1111/j.1469-8137.1971.tb04585.x

[52] Roberts, J.A., Daniels, W.L., Bell, J.C. and Burger, J.A. (1988) Early stages of mine soil genesis in a southwest Virginia spoil lithosequence. Soil Science Society of America Journal, 52, 716-723.

http://dx.doi.org/10.2136/sssaj1988.03615995005200030 $\underline{023 \mathrm{x}}$

[53] Jayachandran, K., Schwab, A.P. and Hetrick, B.A.D. (1989) Mycorrhizal mediation of phosphorus availability: Synthetic iron chelate effects on phosphorus solubilization. Soil Science Society of America Journal, 53, 17011706.

http://dx.doi.org/10.2136/sssaj1989.03615995005300060 $\underline{015 x}$

[54] Richardson, A.E., Hocking, P.J., Simpson, R.J. and George, T.S. (2009) Plant mechanisms to optimize access to soil phosphorus. Crop and Pasture Science, 60, 124-143. http://dx.doi.org/10.1071/CP07125

[55] Schubert, A. and Hayman, D.S. (1986) Plant growth responses to vesicular-arbuscular mycorrhiza. XVI. Effectiveness of different endophytes at different levels of soil phosphate. New Phytologist, 103, 79-90. http://dx.doi.org/10.1111/j.1469-8137.1986.tb00598.x

[56] Zhu, Y.-G., Laidlaw, A.S., Christie, P. and Hammond, M.E.R. (2000) The specificity of arbuscular mycorrhizal fungi in perennial ryegrass-white clover pasture. Agriculture, Ecosystems and Environment, 77, 211-218. http://dx.doi.org/10.1016/S0167-8809(99)00087-0

[57] Ronsheim, M.L. and Anderson, S.E. (2001) Populationlevel specificity in the plant-mycorrhizae associations alters intraspecific interactions among neighboring plants. Oecologia, 128, 77-84. http://dx.doi.org/10.1007/s004420000625

[58] Bevor, J.D. (2002) Host-specificity of AM fungal population growth rates can generate feedback on plant growth. Plant and Soil, 244, 281-290. http://dx.doi.org/10.1023/A:1020221609080

[59] Sanders, I.R. (2003) Preference, specificity and cheating in the arbuscular mycorrhizae symbiosis. Trends in Plant
Science, 8, 143-145. http://dx.doi.org/10.1016/S1360-1385(03)00012-8

[60] Noyd, R.K., Pfleger, F.L. and Russelle, M.P. (1995) Interactions between native prairie grasses and indigenous arbuscular mycorrhizal fungi: Implications for reclamation of taconite iron ore tailing. New Phytologist, 129, 651-660. http://dx.doi.org/10.1111/j.1469-8137.1995.tb03034.x

[61] Collins, C.D. and Foster, B.L. (2009) Community-level consequences of mycorrhizae depend on phosphorus availability. Ecology, 90, 2567-2576. http://dx.doi.org/10.1890/08-1560.1

[62] Newman, P.R. and Moser, L.E. (1988) Seedling root development and morphology of cool-season and warmseason forage grasses. Crop Science, 28, 148-151. http://dx.doi.org/10.2135/cropsci1988.0011183X0028000 $10032 \mathrm{x}$

[63] Thorne, M., Rhodes, L. and Cardina, J. (2013) Effectivity of arbuscular mycorrhizal fungi collected from reclaimed mine soil and tallgrass prairie. Open Journal of Ecology, 3, 224-233. http://dx.doi.org/10.4236/oje.2013.33026

[64] Lambert, D.H. and Cole Jr., H. (1980) Effects of mycorrhizae on establishment and performance of forage species in mine spoil. Agronomy Journal, 72, 257-260. http://dx.doi.org/10.2134/agronj1980.0002196200720002 $\underline{0003 \mathrm{x}}$

[65] Evanylo, G.K., Abaye, A.O., Dundas, C., Zipper, C.E., Lemus, R., Sukkariyah, B. and Rockett, J. (2005) Herbaceous vegetation productivity, persistence, and metals uptake on a biosolids-amended mine soil. Journal of Environmental Quality, 34, 1811-1819. http://dx.doi.org/10.2134/jeq2004.0329

[66] Carrow, R.N. (1980) Influence of soil compaction on three turfgrass species. Agronomy Journal, 72, 1038-1042. http://dx.doi.org/10.2134/agronj1980.0002196200720006 $\underline{0041 x}$

[67] Thorne, M. and Cardina, J. (2011) Prairie grass establishment on calcareous reclaimed mine soil. Journal of Environmental Quality, 40, 1824-1834. http://dx.doi.org/10.2134/jeq2010.0052

[68] Dewald, C.L., Henry, J., Bruckerhoff, S., Ritchie, J., Dabney, S., Shepherd, D., Douglas, J. and Wolf, D. (1996) Guidelines for establishing warm season grass hedges for erosion control. Journal of Soil and Water Conservation, 51, 16-20. http://www.jswconline.org/content/51/1/16.extract

[69] Ritchie, J.C., Kemper, W.D., Englert, J.M. and Krizek, D.T. (2000) Grass hedges for erosion control. In: Ritchie, J.C., Dickerson, J.A. and Ritchie, C.A., Eds., Proceedings of the 2nd Eastern Native Grass Symposium, Baltimore, 17-19 November 1999, 283-289.

[70] Edwards, S., Douglas, J. and Bloodworth, H. (2000) Clipping effect on yield and quality of eastern gamagrass, switchgrass, and bermudagrass. In: Ritchie, J.C., Dickerson, J.A. and Ritchie, C.A., Eds., Proceedings of the $2 n d$ Eastern Native Grass Symposium, Baltimore, 17-19 November 1999, 121-126. 